\title{
Oxidative Stress in Preterm Infants: Overview of Current Evidence and Future Prospects
}

\author{
Raffaele Falsaperla ${ }^{1}$, Filadelfo Lombardo ${ }^{2}$, Federica Filosco ${ }^{2}$, Catia Romano ${ }^{3}$, \\ Marco Andrea Nicola Saporito ${ }^{1}\left(\mathbb{D}\right.$, Federica Puglisi ${ }^{1}$, Ettore Piro ${ }^{4}{ }^{\mathbb{D}}$, \\ Martino Ruggieri ${ }^{5}$ and Piero Pavone ${ }^{5, *}$ (B)
}

1 Neonatal Intensive Care, AUO San Marco-Policlinico, University of Catania, 95123 Catania, Italy; raffaelefalsaperla@hotmail.com (R.F.); marcosaporito@hotmail.com (M.A.N.S.); federicapuglisi@gmail.com (F.P.)

2 Postgraduate Training Program in Pediatrics, Department of Clinical and Experimental Medicine, University of Catania, Catania street Santa Sofia 78, 95123 Catania, Italy; delfo.lombardo@gmail.com (F.L.); federica.filosco@gmail.com (F.F.)

3 Child and Adolescent Neuropsychiatry, Department Clinical and Experimental Medicine, University of Catania, 95123 Catania, Italy; catiaromano@alice.it

4 University Hospital "P. Giaccone", Department of Sciences for Health Promotion, Maternal Infant Care, Internal Medicine and Medical Specialties "G. D'Alessandro", Neonatal Intensive Care Unit, 90121 Palermo, Italy; ettore.piro@unipa.it

5 Department of Clinical and Experimental Medicine Section of Pediatrics and Child Neuropsychiatry, AUO San Marco-Policlinco, University of Catania, 95123 Catania, Italy; mruggie@unict.it

* Correspondence: ppavone@unict.it; Tel.: +39-095-7435254; Fax: +39-095-7436632

Received: 1 May 2020; Accepted: 29 June 2020; Published: 7 July 2020

\begin{abstract}
Preterm birth (PTB), defined as parturition prior to 37 weeks of gestation, is the leading cause of morbidity and mortality in the neonatal population. The incidence and severity of complications of prematurity increase with decreasing gestational age and birthweight. The aim of this review study is to select the most current evidence on the role of oxidative stress in the onset of preterm complication prevention strategies and treatment options with pre-clinical and clinical trials. We also provide a literature review of primary and secondary studies on the role of oxidative stress in preterm infants and its eventual treatment in prematurity diseases. We conducted a systematic literature search of the Medline (Pubmed), Scholar, and ClinicalTrials.gov databases, retroactively, over a 7-year period. From an initial 777 articles identified, 25 articles were identified that met the inclusion and exclusion criteria. Of these, there were 11 literature reviews: one prospective cohort study, one experimental study, three case-control studies, three pre-clinical trials, and six clinical trials. Several biomarkers were identified as particularly promising, such as the products of the peroxidation of polyunsaturated fatty acids, those of the oxidation of phenylalanine, and the hydroxyl radicals that can attack the DNA chain. Among the most promising drugs, there are those for the prevention of neurological damage, such as melatonin, retinoid lactoferrin, and vitamin E. The microbiome also has an important role in oxidative stress. In conclusion, the most recent studies show that a strong relationship between oxidative stress and prematurity exists and that, unfortunately, there is still little therapeutic evidence reported in the literature.
\end{abstract}

Keywords: oxidative stress; preterm; future prospects; review; antioxidant

\section{Introduction}

Preterm birth (PTB), defined as parturition prior to 37 weeks of gestation, is the leading cause of morbidity and mortality in the neonatal population. The incidence and severity of complications of 
prematurity increase with decreasing gestational age and birthweight. Every year, about 15 million babies are premature (more than one in ten of all babies born around the world). All newborns are vulnerable, but preterm babies are acutely so. Many preterm babies require special care just to remain alive. Newborn deaths - those in the first month of life-account for $40 \%$ of all deaths among children less than 5 years old. Prematurity is the world's single biggest cause of newborn death, and the second leading cause of all child deaths, after pneumonia. Many of the preterm babies who survive face a lifetime of disability [1]. Multiple prospective studies have reported that premature newborns have higher risks of long-term neurodevelopmental disabilities, such as intellectual disability (ID), blindness, neurosensorial hearing loss, and cerebral palsy $(\mathrm{CP})$. There are several risk factors accounting for prematurity, such as assisted reproductive technologies that increase the rate of multiple births (twins, triplets, or quadruples) and advanced maternal age [2]. Teenage pregnancy could also be a risk factor for prematurity, but the putative role of this factor is controversial and seems to have declined in the last 10 years [2,3]. Other maternal causes potentially related to premature births are inflammatory, hormonal, and neurochemical pathologies that could influence a mother's ability to take appropriate care of the baby once born [4].

Some complications (e.g., necrotizing enterocolitis (NEC), retinopathy of prematurity (ROP), bronchopulmonary dysplasia (BPD), intraventricular hemorrhage (IVH)) are uncommon in late preterm infants. Most complications are related to the dysfunction of immature organ systems. In some cases, complications resolve entirely; in others, residual organ dysfunction remains $[5,6]$. The most common complications in extremely preterm infants are cardiac (patent ductus arteriosus (PDA)), neurological (poor sucking and swallowing reflexes, apneic episodes, IVH, developmental or cognitive delays), ocular (ROP, myopia and/or strabismus), gastrointestinal (feeding intolerance, with increased risk of aspiration, NEC), renal (metabolic acidosis, growth failure), infective (sepsis, meningitis), respiratory (respiratory distress syndrome, respiratory insufficiency of prematurity, chronic lung disease and BPD), and metabolic (hypoglycemia, hyperbilirubinemia, and metabolic bone disease-osteopenia of prematurity) [7-9]. These complications might have a single common denominator: oxidative stress [10]. Oxidative stress is a pathophysiological mechanism associated with spontaneous PTB, which reflects an imbalance between the systemic manifestation of reactive oxygen species (ROS) and a biological system's ability to readily detoxify the reactive intermediates or to repair the resulting damage.

An increase in oxidative stress has been demonstrated in infants requiring an oxygen resuscitation supplement in the delivery room [11].

Sies and Jones affirm how the increased formation of the different ROS leads to molecular damage, denoted as "oxidative distress". The signaling and damaging properties of ROS, in particular the most prevalent and best-studied cellular oxidant $\mathrm{H}_{2} \mathrm{O}_{2}$ and the superoxide anion radical $\left(\mathrm{O}_{2}{ }^{-}\right)$, represent the basis for the concept of redox homeostasis, with its components of oxidative eustress and oxidative distress. Redox signaling is universally integrated with the central homeostatic mechanisms at the molecular, organellar, cellular, tissue, and organismic levels [12].

Disturbances in the normal redox state of cells can cause toxic effects through the production of peroxides and free radicals that damage all components of the cell, including proteins, lipids, and DNA. Oxidative stress from oxidative metabolism causes base damage and DNA strand breaks. Base damage is mostly indirect and caused by ROS-generated $\mathrm{O}_{2}{ }^{-}$(superoxide radical), $\mathrm{OH}$ (hydroxyl radical), and $\mathrm{H}_{2} \mathrm{O}_{2}$ (hydrogen peroxide). Indeed, the highly reactive hydroxyl radical reacts with the heterocyclic DNA bases and the sugar moiety near. At diffusion-controlled rates, hydrated electron and $\mathrm{H}$ atom also add to the heterocyclic bases. These reactions lead to adduct radicals, further reactions of which yield numerous products [13]. Furthermore, some ROS act as cellular messengers in redox signaling. Thus, oxidative stress can disrupt normal mechanisms of cellular signaling, and thereby cause organ damage.

Currently, an antioxidant is defined as any substance able to eliminate ROS and their derivatives [14]. In chemistry, "anti-oxidant" is simply conceived as "a compound that removes reactive species, mainly those oxygen-derived" [15]. Their functions can be classified into distinct defense lines, 
according to their mechanisms of action: (a) preventative agents that suppress new radicals formation (which includes enzymes, such as superoxide dismutase (SOD), catalase (CAT) and glutathione peroxidase (GPX), proteins that bind metals, like ferritin and ceruloplasmin, and minerals such as selenium (Se), copper $(\mathrm{Cu})$, and zinc $(\mathrm{Zn})[16,17]) ;(\mathrm{b})$ radical scavenging agents that inhibit chain initiation and/or propagation, which includes glutathione, albumin, vitamins $\mathrm{C}$ and $\mathrm{E}$, carotenoids, and flavonoids; (c) repair and de novo enzymes that repair and reconstitute cell membranes, which include lipases, proteases, DNA repair enzymes, transferases, and methionine-sulfoxide reductases; and (d) adaptation agents that generate appropriate antioxidant enzymes and transfer them to the essential site of action [14,18]. Another category of antioxidants is peroxiredoxins (Prxs), a ubiquitous family of cysteine-dependent peroxidase enzymes that play dominant roles in regulating peroxide levels within cells. In addition, Prxs might act as modulators of inflammation, protecting against cell death and facilitating tissue repair after damage $[19,20]$. In addition, the potential for intracellular free radical production is greatly reduced by the ability of mitochondrial cytochrome oxidase to function catalytically in the electron transport chain without releasing ROS [8-21].

Thus, a possible correlation between oxidative stress and the development of complications in premature babies led us to perform an analysis of the available literature. Here, we synthesize recent findings on the role of oxidative stress in the onset of preterm complications, prevention strategies, and treatment options.

\section{Search Strategy}

We aimed to select the most current evidence on the role of oxidative stress in the onset of preterm complications, prevention strategies, and treatment options. We reviewed the literature (primary and secondary studies) on the role of oxidative stress in preterm infants, as well as its prevention. We searched the Medline (Pubmed), Scholar, and ClinicalTrials.gov databases retroactively over a 5-year search period. The following search terms were used: oxidative stress, free radical, antioxidant, redox, and ROS paired with preterm, preterm birth, preterm delivery, prematurity, premature birth, and premature delivery, "free radicals preterm", "anti-oxidant preterm", "drugs preterm", "neurodevelopment preterm", "pre-clinical trials preterm born", "clinical trials preterm born", "retinopathy of prematurity", "necrotizing enterocolitis preterm", and "bronchopulmonary dysplasia preterm". The inclusion criteria were as follows: original research, written in English, and published after 2013. The exclusion criteria were as follows: pregnancy failure, abortions, stillbirths, preimplantation embryos, PTB from specific infections (e.g., malaria), maternal therapy, sepsis, the population of the clinical trial under study with less than 50 preterms, and pre-clinical trials where clinical trials do not yet exist. Twenty-five articles were selected based on the search criteria. For the sake of a rational flow of thoughts, we decided to first analyze the pre-clinical studies, then the clinical trials.

\section{Results}

From the 777 initially shortlisted articles, we excluded 439 articles because of their publication date (published more than 7 years ago). Subsequently, we read the abstracts of the 338 remaining articles, and, among them, 313 were not included in our final analysis (167 had no relevant information, six were not in English, and 140 matched at least one of the exclusion criteria). Therefore, a total of 25 articles were included in the study. Of these, 11 were literature reviews, one was a prospective cohort study, one was an experimental study, three were case-control studies, three were pre-clinical trials, and six were clinical trials (Figure 1 and Table 1). The articles selected show a relationship between oxidative stress and the possible development of complications in the preterm. Furthermore, given the absence of evidence for the treatment of oxidative stress in the preterm, we have selected three pre-clinical trials that evaluate the use of certain molecules able to prevent the development of neurological, gastroenteric, and respiratory complications (Table 2). In addition, six therapeutic clinical trials were included, reporting evidence of a protective role against the development of oxidative stress and neuronal damage and/or NEC, as the other trials did not comply with the selection criteria (Table 3). 
Table 1. Papers included in the analysis.

\begin{tabular}{|c|c|c|c|c|}
\hline Type of Study & Review Article & Experimental Study & Preclinical trial & Clinical trial \\
\hline 2020 & & $\begin{array}{c}\text { DOI: 10.1177/1099800419900231 [17] } \\
\text { DOI: } 10.1016 / \text { j.freeradbiomed.2019.02.032 [5] }\end{array}$ & & $\begin{array}{l}\text { ClinicalTrials.gov Identifier: NCT04235673 [22] } \\
\text { ClinicalTrials.gov Identifier: NCT04304807 [23] }\end{array}$ \\
\hline 2019 & $\begin{array}{l}\text { DOI: 10.1016/j.freeradbiomed.2019.02.019 [6] } \\
\text { DOI: 10.1016/j.resp.2019.05.006 [24] } \\
\text { DOI: 10.1016/j.freeradbiomed.2019.06.008 [7] } \\
\text { DOI: 10.1016/j.freeradbiomed.2019.04.029 [21] }\end{array}$ & DOI: 10.1093/biolre/ioz119 [25] & $\begin{array}{l}\text { DOI: 10.1186/s12931-019-1063-5 [26] } \\
\text { DOI: 10.1186/s12974-019-1486-4. [27] } \\
\text { DOI: 10.1016/j.biopha.2018.11.023 [28] }\end{array}$ & \\
\hline 2018 & $\begin{array}{c}\text { DOI: 10.3389/fped.2018.00369 [10] } \\
\text { DOI: 10.3390/antiox7120193 [29] } \\
\text { DOI: 10.1155/2018/7397659 [30] } \\
\text { DOI: } 10.1177 / 1099800418791028[16] \\
\text { DOI: } 10.1016 / \text { /.redox.2018.04.022 [31] }\end{array}$ & & & ClinicalTrials.gov Identifier: NCT03154723 [32] \\
\hline 2017 & DOI: 10.1016/j.redox.2017.03.011 [33] & DOI: 10.1016/j.mrgentox.2017.10.003 [34] & & \\
\hline 2016 & & DOI: 10.1093/molehr/gav074 [35] & & \\
\hline 2015 & DOI: 10.1016/j.arcped.2015.05.019 [36] & & & ClinicalTrials.gov Identifier: NCT01193270 [37] \\
\hline 2014 & & & & ClinicalTrials.gov Identifier: NCT02068807 [38] \\
\hline 2013 & & & & ClinicalTrials.gov Identifier: NCT01172236 [39] \\
\hline
\end{tabular}


Table 2. Preclinical studies on Substances that prevent oxidative stress in preterm.

\begin{tabular}{|c|c|c|c|}
\hline Substances under Study & $\alpha_{1}$-Microglobulin & Caffeine & Ankaferd Blood Stopper ${ }^{\circledR}$ \\
\hline Preclinical trials & $\begin{array}{l}\text { The heme and A1M confers early protection of the } \\
\text { immature brain following preterm intraventricular } \\
\text { hemorrhage J Neuroinflammation }\end{array}$ & $\begin{array}{l}\text { Antioxidative effects of caffeine in a hyperoxia-based rat } \\
\text { model of bronchopulmonary dysplasia }\end{array}$ & $\begin{array}{c}\text { Therapeutic and preventative effects of ankaferd } \\
\text { blood stopper in an experimental necrotizing } \\
\text { enterocolitis model }\end{array}$ \\
\hline Authors & Olga Romantsik, et al. [27] & Stefanie Endesfelder, et al. [26] & Mehmet Buyuktiryaki, et al. [28] \\
\hline Year of publication & 2019 & 2019 & 2019 \\
\hline Cavy (animal) & Rabbits pups & Rats pups & Rats pups \\
\hline Molecule & Protein & Methylxanthine & Protein \\
\hline Mechanisms of action & $\begin{array}{c}\text {-Heme binding } \\
\text {-Reductase activity } \\
\text {-Radical scavenging } \\
\text {-Binding to mitochondria } \\
\end{array}$ & $\begin{array}{c}\text {-Reduced oxidative DNA damage } \\
\text {-Protective interference with the oxidative stress response } \\
\text {-Antagonism of adenosine receptors } \\
\text {-Full blocking of hyperoxia-induced oxidative }\end{array}$ & $\begin{array}{c}\text {-Significantly reduced apoptosis } \\
\text {-Reduction intestinal lesion } \\
\text {-Antioxidant, antinflammatory, and antiapoptotic } \\
\text { properties }\end{array}$ \\
\hline Distribution & $\begin{array}{l}\text { Periventricular cerebellar regions with high } \\
\text { plasticity (white matter, subventricular zone, corpus } \\
\text { callosum, corona radiata, thalamocortical projection) }\end{array}$ & Pulmonary & Intestinal \\
\hline Administration & Intracerebroventricular & Intravenous & Intraperitoneal \\
\hline Posology & $25 \mu \mathrm{L}$ & $10 \mathrm{mg} / \mathrm{kg}$ every $48 \mathrm{~h}$ beginning on the day of birth & $2 \mathrm{~mL} / \mathrm{kg}$ by diluting $2 \mathrm{~mL}$ with saline at a ratio of $1: 3$ \\
\hline Protective role & $\begin{array}{l}\text { neuroprotective against brain damage following } \\
\text { preterm IVH }\end{array}$ & BPD & NEC \\
\hline
\end{tabular}

Radical scavenger $\alpha_{1}$-microglobulin (A1M); bronchopulmonary dysplasia (BPD); necrotizing enterocolitis (NEC) 
Table 3. Clinical studies on drugs that prevent oxidative stress in preterm.

\begin{tabular}{|c|c|c|c|c|c|c|}
\hline Drugs & Lactoferrin & Lutein & Vitamin E & Vitamin A & Studies of & Melatonin \\
\hline Clinical trials & $\begin{array}{l}\text { Supplementation with Lactoferrin in } \\
\text { Preterm } \\
\text { Newborns (lactoprenew) }\end{array}$ & $\begin{array}{l}\text { Evaluation of Antioxidant } \\
\text { Activity of Oral Lutein in } \\
\text { Preterm and Term Newborn }\end{array}$ & $\begin{array}{l}\text { Vitamin E for Extremely } \\
\text { Preterm Infants }\end{array}$ & $\begin{array}{l}\text { Effects of Early Vitamin A } \\
\text { Supplementation on the Risk } \\
\text { for Retinopathy of } \\
\text { Prematurity in Extremely } \\
\text { Preterm Infants }\end{array}$ & $\begin{array}{l}\text { Oral Melatonin as } \\
\text { Neuroprotectant in Preterm } \\
\text { Infants }\end{array}$ & $\begin{array}{l}\text { Effect of Melatonin on Feeding } \\
\text { Intolerance and Incidence of } \\
\text { Necrotizing Enterocolitis in } \\
\text { Preterm Infants }\end{array}$ \\
\hline Date & January 2013 & February 2014 & November 2015 & September 2018 & January 2020 & March 2020 \\
\hline Study phase & 4 & 2 & 1 & Not Applicable & Not Applicable & 4 \\
\hline Population & $\begin{array}{c}\text { Birthweight } \leq 1500 \text { grand/or gestational } \\
\text { age } \leq 32 \text { weeks }\end{array}$ & $\begin{array}{l}\text { Preterm born neonates with } \\
\text { gestational age }<30 \text { weeks }\end{array}$ & $\begin{array}{c}\text { Preterm infants }<27 \text { weeks' } \\
\text { gestation and }<1000 \mathrm{~g} \text { birth } \\
\text { weight }\end{array}$ & $\begin{array}{l}\text { Premature infants weighing } \\
\text { less than } 1500 \mathrm{~g}\end{array}$ & $\begin{array}{l}\text { Neonates born before } 29+ \\
\text { 6-week gestation }\end{array}$ & Preterm infants $<37$ week \\
\hline Total Population & 1300 & 100 & 93 & 262 & 60 & 90 \\
\hline Mechanisms of action & $\begin{array}{l}\text { Binds iron with high affinity and its } \\
\text { structure is unusually resistant to } \\
\text { proteolytic degradation. } \\
\text { Antioxidant sequestering free ions of } \\
\mathrm{Fe}^{2+} \text { and thus preventing lipid } \\
\text { peroxidation and subsequent milk } \\
\text { oxidation }\end{array}$ & $\begin{array}{l}\text { Activity of inhibition of } \\
\text { peroxidation of membrane lipids } \\
\text { is peculiarly important for the } \\
\text { photoreceptors and neurons }\end{array}$ & $\begin{array}{l}\text { Effective lipid } \\
\text { membrane antioxidant }\end{array}$ & $\begin{array}{l}\text { Effective lipid } \\
\text { membrane antioxidant }\end{array}$ & $\begin{array}{c}\text { Potent } \\
\text { antioxidant/-inflammatory effect }\end{array}$ & $\begin{array}{c}\text { potent } \\
\text { antioxidant/-inflammatory effect }\end{array}$ \\
\hline Posology & $100 \mathrm{mg} / \mathrm{day}$ & $\begin{array}{l}0.28 \mathrm{mg} \text { of lutein in two doses: } \\
\text { within } 6 \mathrm{~h}\end{array}$ & $\begin{array}{l}\alpha \text {-tocopheryl acetate } 50 \mathrm{IU} / \mathrm{kg} \text {. } \\
\quad 1 \text { dose }\end{array}$ & 1500 IU/day for 28 day & $3 \mathrm{mg} / \mathrm{kg} /$ day for 15 days & $\begin{array}{l}20 \mathrm{mg} / \text { day in two doses of } 10 \mathrm{mg} \\
\text { each with a } 1 \text {-h interval in } \\
\text { between }\end{array}$ \\
\hline Administration & Enteral & Enteral & Intragastrical & Enteral & Enteral & Enteral \\
\hline Protective role & Neuroprotective & $\begin{array}{l}\text { Neuroprotective } \\
\text { ROP }\end{array}$ & $\begin{array}{l}\text { Reduce the incidence of death or } \\
\text { development of neural } \\
\text { impairment }\end{array}$ & ROP & $\begin{array}{l}\text { Neuroprotectant for cerebral } \\
\text { ischemia }\end{array}$ & NEC \\
\hline
\end{tabular}

Retinopathy of prematurity (ROP); necrotizing enterocolitis (NEC). 


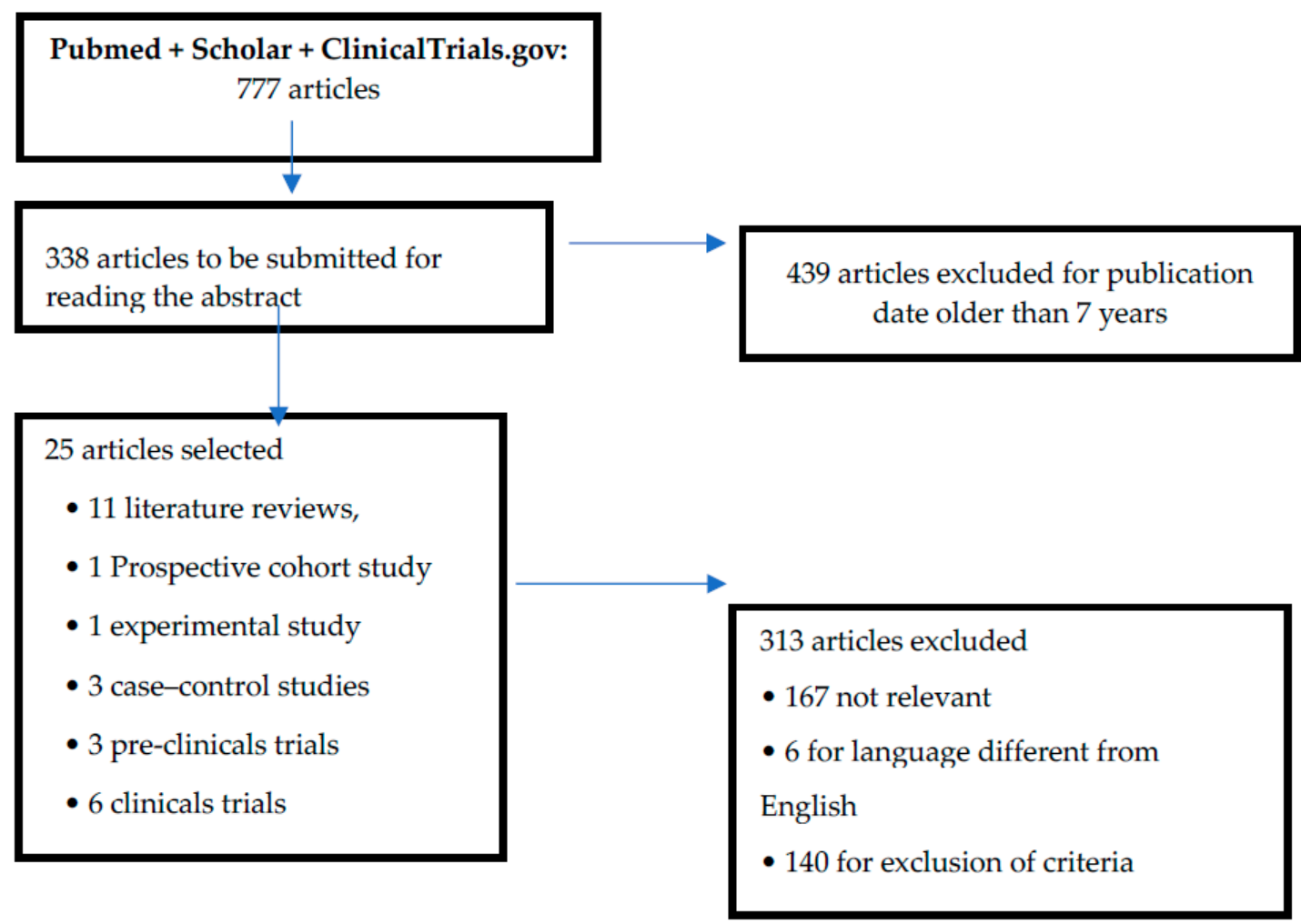

Figure 1. Flow diagram of the literature selection and review process.

\section{Discussion}

Oxidative stress or, rather, the imbalance between the newborn's oxidizing and antioxidant factors, seems to play an important role in the onset of the main pathologies of the premature infant, such as BPD, ROP, NEC, IVH, periventricular leukomalacia (PVL), and punctated white matter lesions (PWMLs). Multiple studies have reported that oxidative stress is among the main causes of PWMLs, with which it shares risk factors, such as hyperoxia, hypoxia, ischemia-reperfusion hemorrhage, and maternal/fetal inflammation. Indeed, the microglial inflammatory response in the cerebral white matter can generate free radicals; for this reason, the optimal concentration of oxygen for the resuscitation of preterm infants is strictly monitored [10].

Other studies have shown a close association between oxidative stress and NEC. The first study, which evaluates the global oxidizing/antioxidant status of infants with and without NEC, highlighted how preterms with NEC had higher values of total oxidant status (TOS) and on the oxidative stress index (OSI) than did controls [40,41]. The serum levels of antioxidant capacity (TAC) were measured as described by Erel [42], using the bleaching of the characteristic color of a more stable 2,2'-azino-bis (3-ethylbenz-thiazoline- 6-sulfonic acid) radical cation by antioxidants. Total oxidant status (TOS) was measured as the oxidation of ferrous ion to ferric ion in the presence of various oxidative species in acidic medium and the measurement of the ferric ion by xylenol orange, as described by Erel [43]. The TOS to TAC ratio was defined as the OSI and used as an indicator of the degree of oxidative stress [44]. The second study showed how higher levels of oxidative markers in cord blood plasma were present in preterm infants with NEC [30]. Lavu et al., studied changes in glycogen synthase kinase 3 beta (GSK3 $\beta$ ) activity and its regulation by p38 mitogen-actived protein kinase (p38MAPK) in effecting senescence to further delineate the molecular mechanisms involved in senescence. These authors found that OS-induced P-p38MAPK activation is associated with functional downregulation of GSK3 $\beta$ and arrest of cell cycle progression and senescence of amnion cells. Lack of nuclear translocation of $\beta$-Cat and its excretion via exosomes further supports the postulation that GSK3 $\beta$ downregulation by p38MAPK might stop cell proliferation preceding cell senescence [25]. This study can be paired with the study by 
Dutta et al., who found mechanistic differences between PTB and PPROM by revealing differences in fetal membrane redox status, oxidative stress-induced damage, distinct signaling pathways, and senescence activation [35].

Forde et al., underlined how care in a neonatal intensive care unit (NICU) is crucial for preventing the onset of oxidative stress in preterm infants, assessing the impact of kangaroo mother care (KMC; in which a parent holds an infant skin-to-skin on their bare chest for extended periods of time), on physiologic measures of stress (abdominal temperature, heart rate, oxygen saturation, perfusion index, near-infrared spectrometry), oxidative stress, and energy conservation in preterm infants. These authors detected significantly lower levels of urinary allantoin, a biochemical marker of oxidative stress, in preterm infants treated with $1 \mathrm{~h}$ of KMC the day prior, compared to controls, who had been treated with incubator care the previous day. This suggests that infants treated with KMC exhibit lower inflammatory tone over time, lending support to the practice of early KMC intervention in the NICU to ultimately reduce stress and promote the health and wellbeing of preterm infants [17].

In a study comparing DNA strand breaks as one of many consequences of DNA oxidation in white blood cells, malondialdehyde (an oxidative stress marker), catalase, superoxide dismutase activity, and total antioxidant capacity (markers of antioxidant defense) in the cord blood plasma of a group of 25 preterms and 25 full-term births, Norishadkam highlighted the greater susceptibility to damage to the DNA of preterms compared to babies born at term [34]. Cai et al., assessed the effect of feeding practices on gut microbiome development and oxidative stress in preterm infants [5]. Preterm infants fed human milk with human milk fortifier or formula-only diets showed a significant increase in F2-isoprostane levels $(p<0.05)$ relative to those fed a diet of human milk with formula. The gut microbiome of the infants fed the human milk with a fortifier diet showed a lower abundance of Veillonella $(p<0.05)$ compared to that of infants fed the human milk with formula diet. The gut microbiome of the infants fed the formula-only diet showed the lowest microbial diversity and the highest relative abundance of Terrisporobacter $(p<0.05)$ compared to the gut microbiomes of the other infants. A low abundance of Veillonella might be associated with the increased oxidative stress of infants who were fed breast milk with a fortifier. By contrast, a high abundance of Terrisporobacter and Peptoclostridium and low bacterial diversity might be associated with increased oxidative stress in infants who are fed formula [15].

These results show that feeding practices affect the bacterial diversity and composition of the gut microbiome, which is associated with oxidative stress in the very low birth weight (VLBW) of preterm infants [8,45]. As reported by Marseglia et al. [21], the 2018 Odzemir study shows how the serum neutrophil-lymphocyte ratio (NLR) appears to have a predictive role in the development of OS-related diseases, as in the case of BPD; the periods of hypoxia and reoxygenation are sensitive, use the activation of neutrophils, and are responsible for the increase in oxidative metabolism, thus forming species reactive to oxygen and nitrogen [ROS and reactive nitrogen species (RNS), respectively] [46]. If these toxic products are not inactivated, their high chemical reactivity leads to damage to a variety of cellular macromolecules, including proteins, carbohydrates, lipids, and nucleic acid; this damage can progress to the death of lung cells [21].

These macromolecules, as described by the National Institutes of Health, are categorized as biomarkers and, as such, are being studied in the context of the evaluation of different biological processes (Biomarkers Definitions Working Group, 2001).

Analytical methods available to study OS include those aimed at detecting a potential risk of oxidative stress, such as non-protein bound iron (NPBI) with its capacity to generate $\mathrm{OH}$ through Fenton reaction, and those aimed at detecting direct oxidative damage to lipids, proteins, and DNA (Figure 1). In addition, stress response proteins, ROS-forming enzymes (e.g., xanthine oxidase (XO), uncoupled nitric oxide synthases (NOS), and nicotinamide adenine dinucleotide phosphate (NADPH) oxidase (NOX)), and the activity of antioxidant enzymes (e.g., superoxide dismutase (SOD), catalase, and glutathione peroxidase (GPX)) can be used as OS biomarkers. [47] To better understand the mechanisms underlying oxidative stress, antioxidant defense, and redox signaling, it is essential to 
assess the protein thiol redox state. However, this state is seldom assessed immunologically because of the inability to distinguish reduced and reversibly oxidized thiols by Western blotting [48-54].

A modern, underappreciated opportunity exists to use Click PEGylation to realize the transformative power of simple, time and cost-efficient immunological techniques. Click PEGylation harnesses selective, bio-orthogonal Click chemistry to separate reduced and reversibly oxidized thiols by selectively ligating a low molecular weight polyethylene glycol moiety to the redox state of interest [55].

The dangerous effects of FRs are due to their property lack of stability and ability to react with polyunsaturated fatty acids of cell membranes, proteins, polysaccharides, and nucleic acids [56]. Therefore, clinically useful biomarkers should be measured in a reliable and reproducible way (it must be reasonably stable and present in accessible tissue or fluid), but it should also satisfy at least one requirement, such as showing the specificity of the disease, having prognostic power or correlating with disease activity [57]. There are several molecules that could be used, in theory, as biomarkers, but, to date, these are not used in clinical practice. The main commitments are described below.

\subsection{Molecules that Suffer Damage from FR}

\subsubsection{Proteins}

Several amino acid residues can undergo oxidative modifications, including the oxidation of sulfur-containing amino acid residues, the hydroxylation of aromatic groups, the nitration of tyrosine residues, the chlorination of aromatic groups, or the conversion of some amino acid residues to carbonyl derivatives [29]. Proteins are one of the main targets of ROS and RNS damage. Various amino acid residues can undergo oxidative changes, such as oxidation of sulfur-containing amino acid residues, hydroxylation of aromatic groups, nitration of tyrosine residues, chlorination of aromatic groups, or conversion of some carbonyl-derivative amino acid residues. In the neonatal period, one of the biomarkers typically measured is the oxidation of phenylalanine (Phe). The oxidation of Phe is due to the attack of the hydroxyl radical $(\mathrm{OH})$, which converts Phe into ortho-tyrosine (o-Tyr) or meta-tyrosine (m-Tyr). Moreover, other byproducts of tyrosine, such as 3-nitrotyrosine (3NO2-Tyr) and 3-chlorothyrosine (3Cl-Tyr), are also useful as biomarkers of nitrosative stress and inflammation, respectively [29]. In the presence of peroxynitrite (ONOO), p-Tyr can be converted into 3NO2-Tyr, a specific biomarker for protein nitration [58]. Protein nitration and RNS signaling play a role in cellular functions, such as inflammatory responses and apoptosis [59]. In fact, in another study, the quantification of the $3 \mathrm{Cl}-\mathrm{Tyr} / \mathrm{p}$-Tyr ratio in human milk samples could be of potential interest for the assessment of inflammation in different clinical scenarios [60]. Similarly, 3Cl-Tyr, formed by the attack of hypochlorous acid on $\mathrm{p}$-Tyr through the action of the enzyme myeloperoxidase (MPO), is considered a useful inflammatory biomarker. The results of these determinations are expressed as ratios, such as the $\mathrm{o}-\mathrm{Tyr} / \mathrm{Phe}, \mathrm{m}-\mathrm{Tyr} / \mathrm{Phe}, 3 \mathrm{NO} 2-\mathrm{Tyr} / \mathrm{p}-\mathrm{Tyr}$, and 3Cl-Tyr/p-Tyr ratios. These markers have been validated and extensively applied in the clinical setting in various human biofluid matrices, such as amniotic fluid, urine, plasma, cerebrospinal fluid, or human milk in the newborn period [16,24,29,31,36,61-64]. In urine, in a pre-clinical study conducted on pig pups, we found a significant increase in both urinary o-tyrosine and 8-oxodG levels after $15 \mathrm{~min}$ of hyperoxia by resuscitation [62]. Prematurity is associated with protracted oxidative stress, and human milk is partially protective, as there is a reduction in biomarkers in the urine like o-Tyr/Phe [63]

\subsubsection{Lipids}

The lipid peroxidation process and the damage by its byproducts are among those most described in the literature on free radical damage. This process can take place enzymatically, through the oxidation of arachidonic acid by cyclooxygenase and lipoxygenase, with the formation of prostaglandins, prostacycline, thromboxane, leukotrienes, and lipoxins. All polyunsaturated fatty acids (PUFAs), as such, can undergo this enzymatic oxidation, leading to the formation of protectins, maresins [65], 
and dihydroxy-PUFAs (diHPUFAs). However, a relevant finding is that we did not identify evidence of the presence of enzymatic oxidation of fatty acid-derived lipid peroxidation markers in preterm infants. Neonatal markers of PUFA peroxidation include isoprostanes (IsoPs) [66,67], isofurans (IsoFs), dihomo-isoprostanes (Dihomo-IsoPs), neuroprostanes (NeuroPs), and neurofurans (NeuroFs). These are non-enzymatic products from the oxidation of amino acid-free radicals and other PUFAs, and are chemically stable. These compounds have been detected electively in lipid-rich tissues, such as brain tissue, which, being rich in polyunsaturated lipids, is highly sensitive to oxidative stress [16-21,25,29,30,33-35,40,42-59,61,65-67].

Deshpande and Cai performed a double-blind, randomized controlled trial conducted in very preterm neonates (between 23 and $<28$ weeks' gestation) [68]. This assessed 5 days of parenteral nutrition with a lipid emulsion containing $80 \%$ olive oil and $20 \%$ soybean oil vs. a pure soybean oil emulsion. The rationale for this study was that olive oil could favor-preterm neonates by reducing oxidative injury, but the authors did not find significant differences. Plasma F2-isoprostane levels were used as a marker of in vivo oxidative stress and lipid peroxidation, and are considered the "gold-standard" biomarker for this parameter [69].

\subsubsection{Nucleic Acids}

In physiological conditions, DNA is constantly subject to oxidative damage, but DNA repair mechanisms usually correct these alterations. However, oxidative damage to DNA can be complicated by the oxidative alteration of DNA repair enzymes. The oxidation of DNA components by ROS is the main source of damage to DNA, resulting in various modifications, including nucleotide oxidation, filament breaks, base loss, and adduct formation. Hydroxyl radicals can attack the DNA chain and the nitrogen bases of DNA nucleotides or deoxyribose. The main damage for OS to DNA is generally produced by guanosine-based oxidation products, such as 7,8-hydroxy-2'-deoxyguanosine (8-oxodG or 8-OHdG), which can be measured quantitatively in urine, plasma, and cerebrospinal fluid, among others, by high-performance liquid or gas chromatography coupled with mass spectrometry (UPLC-MS/MS) [29,33,58,59,61,65-67]. Sánchez-Illana et al., have described a method for the simultaneous detection of a panel of oxidative stress-related biomarkers for the quantification of damage to proteins and DNA in human breast milk samples. The results demonstrate the feasibility of this method for the analysis of a panel of oxidative stress-related biomarkers (2dG, m-Tyr, 3Cl-Tyr), reporting ranges found in human milk [60].

\subsection{Therapeutical View from Experimental to Clinical Evidence}

The choice of which therapeutic treatment as the principal goal for a reduction in the production of free radicals in premature born is still controversial and challenging. In this setting, even if no guidelines are provided, several pre-clinical and clinical trials allow us to identify some substances as potential antioxidants in this population.

\subsubsection{Pre-Clinical Trials}

Among the pre-clinical studies currently available, the authors of the current manuscripts have identified three main studies. The first, from Romantsik et al., tested the administration of $25 \mu \mathrm{L}$ of intracerebroventricular $\alpha 1$-microglobulin in rabbit pups. This acts through the binding of the heme group and the reduction in the synthesis of free radicals by its reductase activity. $\alpha 1$-microglobulin is distributed to periventricular cerebellar regions with high plasticity, having a neuroprotective effect against brain damage as a result of IVH preterm [27].

The second pre-clinical study evaluated the antioxidant effect of caffeine related to the state of hyperoxia present in a cohort of rat pups with bronchopulmonary dysplasia. Intravenous caffeine $(10 \mathrm{mg} / \mathrm{kg})$ was administered every $48 \mathrm{~h}$, immediately after birth, in order to avoid elevated doses of caffeine outside the therapeutic range that might induce pro-inflammatory responses [70]. This resulted in reduced oxidative damage to DNA, and antagonism of adenosine receptors, a protective action 
against the response to oxidative stress, and complete interruption of oxidative damage induced by pulmonary hyperoxia. All of the abovementioned features have been found to be linked with a protective role in the development of BPD [26]. Pre-clinical data coming from newborn cavies (rats) has raised the hypothesis of a potential caffeine-related loss of weight. This assumption seems to be underlined by some clinical studies [71-73]. However, this is of a temporary nature.

The third pre-clinical study aimed to investigate whether treatment with Ankaferd Blood Stopper ${ }^{\circledR}$ (ABS) reduced the severity of NEC in rat pups in an experimental NEC model. ABS is a folkloric herbal extract used as a hemostatic agent in traditional Turkish medicine [74]. ABS consists of a standardized mixture of Thymus vulgaris, Alpinia officinarum, Vitis vinifera, Glycyrrhiza glabra, and Urtica dioicaplant extracts [75]. ABS influences inflammatory and hemostatic processes via its effect on the endothelium, blood cells, angiogenesis, cellular proliferation, vascular dynamics, and cellular mediators [74-76], through its antioxidant, anti-inflammatory, antimicrobial, anti-apoptotic, and wound healing accelerant properties. In this trial, ABS was administered intraperitoneally to the pups in the NEC group. The drug administration protocol started on day 1 of the study at a dose of $2 \mathrm{~mL} / \mathrm{kg}$ by diluting with $2 \mathrm{~mL}$ of saline at a ratio of 1:3. The intervention group resulted in a significantly reduced apoptosis rate and a reduction in the intestinal lesions. Given the above, the antioxidant, anti-inflammatory, and anti-apoptotic intestinal properties reduced the NEC in this specific context [28] [Table 2].

\subsubsection{Clinical Trials}

Here, we describe the relevant clinical studies, in order of publication. A clinical study conducted by Buonocore at the University of Siena enlisted 1300 newborns with a birth weight of $1500 \mathrm{~g}$ or a gestational age of 32 weeks. The investigated cohort was divided into two groups: the experimental group received a daily dose of $100 \mathrm{mg}$ of lactoferrin at standard therapy, while the control group received only standard therapy. Therefore, the main objective was to evaluate the antioxidant effect and the neuroprotective role of lactoferrin and its ability to reduce diseases of free radicals [39]. This is the first study in the literature to address the role of lactoferrin in preterms. It is well established how lactoferrin is an iron-binding glycoprotein with multiple biological functions (iron absorption, anti-inflammatory, immunomodulatory, antioxidant, host defense mechanism, anti-carcinogenicity) [77,78]. A pre-clinical trial showed great promise in the field of neonatology, and for the care of premature newborns, in this model, lactoferrin could protect the preterm rat brain against cerebral hypoxia-ischemia injury [79].

A study still in experimental phase 2, conducted by the University of Siena in 2014, enrolled 100 preterm born neonates with gestational age $<30$ weeks, reported that retinoic acid (lutein), a derivative of vitamin $\mathrm{A}$, is a neuroprotective factor. This analysis showed the reduction in the outcome ROP through a dose of $0.28 \mathrm{mg}$ of lutein administered enterally every $6 \mathrm{~h}$, and within the first $36 \mathrm{~h}$ of life. These results underline how the inhibition of peroxidation of membrane lipids is of paramount importance for the photoreceptors and neurons [38,80]. Ramani et al., in 2017, suggested that a combination of vitamin A plus retinoic acid might be neuroprotective in extremely preterm mice at higher risk of neurological impairment due to excess oxidative stress [81].

According to a phase 1 study conducted by several US universities in 2015, vitamin E could also be considered a protective element. The purpose of this analysis was to test both the safety and efficacy of administration of one dose of vitamin $\mathrm{E}$, via a tube into the stomach, to extremely preterm infants (less than 27 weeks' gestation and less than $1000 \mathrm{~g}$ weight at birth). This pivotal trial examined whether a single dose of vitamin E would be absorbed into the infants' bloodstreams, increasing serum $\alpha$-tocopherol levels in the target range of $1-3 \mathrm{mg} / \mathrm{dl}$. This was found to be linked with a reduction in the incidence of death or neurodevelopmental impairment [37].

Recently, a review summarized and analyzed the state of the art and relation between vitamin A levels and diseases of premature infants. However, although sufficient evidence suggests that vitamin A supplementation is beneficial in preterm infants, the evidence is still lacking for recommended methods for supplementation and dosing of vitamin A. Therefore, in this clinical trial, vitamin A, with its well-known antioxidant effect on lipid membranes, was administered orally at 1500 IU/day for 
28 days, and seemed to have a protective effect related to the development of the ROP in relation to the control group, in a study of 254 premature infants weighing less than $1500 \mathrm{~g}$ [32].

Melatonin is a naturally occurring neuroendocrine molecule secreted in response to environmental light-dark cycles. Melatonin influences numerous physiological functions, including growth and development, reproduction, and the immune response [82].

Then, acting via specific cell membranes and nuclear receptors, melatonin achieves powerful neuroprotective effect via antioxidant, anti-apoptotic, and anti-inflammatory processes $[83,84]$ and by promoting neuronal and glial development $[85,86]$. Additional indirect antioxidant effects of melatonin include the up-regulation of antioxidant enzymes and, crucially, the preservation of mitochondrial integrity $[87,88]$.

The University of Pavia has carried out a clinical trial on Melatonin (ME), where researchers investigated the protective role against cerebral ischemia through its powerful antioxidant/inflammatory effects. This study aimed to highlight how ME can prevent brain damage due to premature childbirth. ME was administered orally at a dose of $3 \mathrm{mg} / \mathrm{kg} /$ day for 15 days in infants born before gestation of 29 weeks. This was a prospective and randomized study, double-blind controlled, and with two parallel arms. Furthermore, ME was proven to have a good safety profile with no known adverse effects [22].

\subsection{Future Prospects}

The extremely brief half-life of free radicals does not allow for direct measurement of their concentration in clinical settings; therefore, thanks to studies such as those of Stefanovic et al. [7], various analytical strategies have been developed to evaluate the state of oxidation, such as evaluation-both at the extracellular (plasma, serum, urine, amniotic, cerebrospinal fluid) and intracellular (erythrocytes, leukocytes) level—of the oxidoreductive quotient of molecules containing disulfide bridges (SS), such as glutathione in a reduced or oxidized state (GSH or GSSG), or cysteine-cystine (Cys-H or Cys-SS), or the activity of antioxidant enzymes such as SOD, CAT, or GPX. In addition, Stefanovic et al., have developed a new method of evaluation of the redox stage of GSH based on surface-enhanced Raman spectroscopy (SERS), which exploits a silver colloid that improves the GSH signal and allows the accurate measurement of micro-volumes $(20 \mathrm{mcl})$ of blood [7]. This method, associated with the use of UPLC-MS/MS, allows the study of oxidative stress byproducts related to specific tissue components, such as proteins, lipids, carbohydrates, or nucleic acids measured in various body biofluids. Torres-Cuevas et al., have developed a UPLC-MS/MS for recording the profiles of the relative contents of IsoP, IsoF, NeuroP, and NeuroF in a total of 536 urine samples during the first 4 weeks of life in 184 premature infants who did not develop any pathology associated with oxidative stress during the neonatal period [33]. A prospective study of 90 preterm infants in Ain Shams University neonatal intensive care units enrolled infants suffering from food intolerance in the form of abdominal distension, gastric residue, or bloody stool. The first cohort of 45 children was given $20 \mathrm{mg}$ (ME), divided into two daily doses of $10 \mathrm{mg}$ each with a 1-h interval between them, in addition to traditional antibiotic treatment. The second group of 45 children received only standard antibiotic treatment. Both groups were then compared regarding the incidence of necrotizing enterocolitis and the level of the tumor necrosis alpha factor $72 \mathrm{~h}$ after starting treatment as a marker of oxidative stress, having a protective role against the NEC [23].

Evidence derived from the literature strongly supports that melatonin is neuroprotective for acute hypoxic-ischemic perinatal brain injury, mediated via its antioxidant, anti-apoptotic, and anti-inflammatory properties. Melatonin is safe in its administration both during pregnancy and after delivery with respect to the newborn, and can reduce white matter brain injury under conditions of chronic fetal hypoxia [89].

Currently, therapeutic strategies to decrease antioxidant cascade, in neonates, are poor and limited. Future prospective studies should be dedicated to verifying the promise of single pharmacotherapy to determine the optimal therapeutic time window for brain protection and, when possible, to decrease the risk of brain damage [Table 3]. 
The lung microbiome has an important role in the maturation of the immune system [90]; this might act through the production of metabolites, such as tryptophan catabolites, which are agonist of the aryl hydrocarbon receptor (AhR) that regulates the production of antioxidant enzymes [91,92].

Lactobacilli have the ability to metabolize tryptophan into AhR agonists, suggesting an important modulatory role of these bacteria on the OS $[93,94]$. Moreover, a study in mice reported that the injection of Lactobacilli into the lungs could improve alveolar development [95].

All of these findings indicate a potential role of the microbiome in reducing the OS correlated to BPD. This can be explained by their capacity to reduce macrophage production of pro-inflammatory cytokines, which are responsible for amplifying OS [96].

According to the current literature, the relevance of OS biomarkers in preterm is well established, highlighting the importance of identifying high-risk preterm newborns and predicting their shortand long-term outcomes. Overcoming the technical and economic difficulties that preclude the use of OS biomarkers and the appropriate treatments in clinical practice is challenging, but would lead to an improvement for an accurate evaluation of OS and, consequently, the quality of care of neonatal patients.

\section{Conclusions}

The most recent studies show that the relationship between oxidative stress and prematurity is receiving increasing attention from the scientific community. Several biomarkers emerged from our research, such as the products of the peroxidation of polyunsaturated fatty acids (PUFAs), those of the oxidation of phenylalanine, and the hydroxyl radicals that can attack the DNA chain. None of the biomarkers studied and listed above are currently used. Among the most promising drugs, according to our study, are those for the prevention of neurological damage, such as melatonin, retinoid lactoferrin, and vitamin E (Figure 2). The microbiome has an important role in oxidative stress; in fact, the use of lactobacilli might be protective against OS lesions in preterm infants [97]. The search for new biomarkers, the improvement of care within the NICU, and the use of new machines and increasingly precise techniques for the study of oxidative stress products and related pathologies are guiding us towards increasingly targeted interventions (preventive, diagnostic, and therapeutic). Based on this evidence, it is possible to hypothesize that in the coming years, the diagnostic strategies aimed at identifying the risk of the onset of conditions related to oxidative stress will be further refined, and the guidelines for their prevention and treatment will be updated, thereby reducing mortality and morbidity.

\section{OXIDATIVE STRESS AND ACTION OF DRUGS}

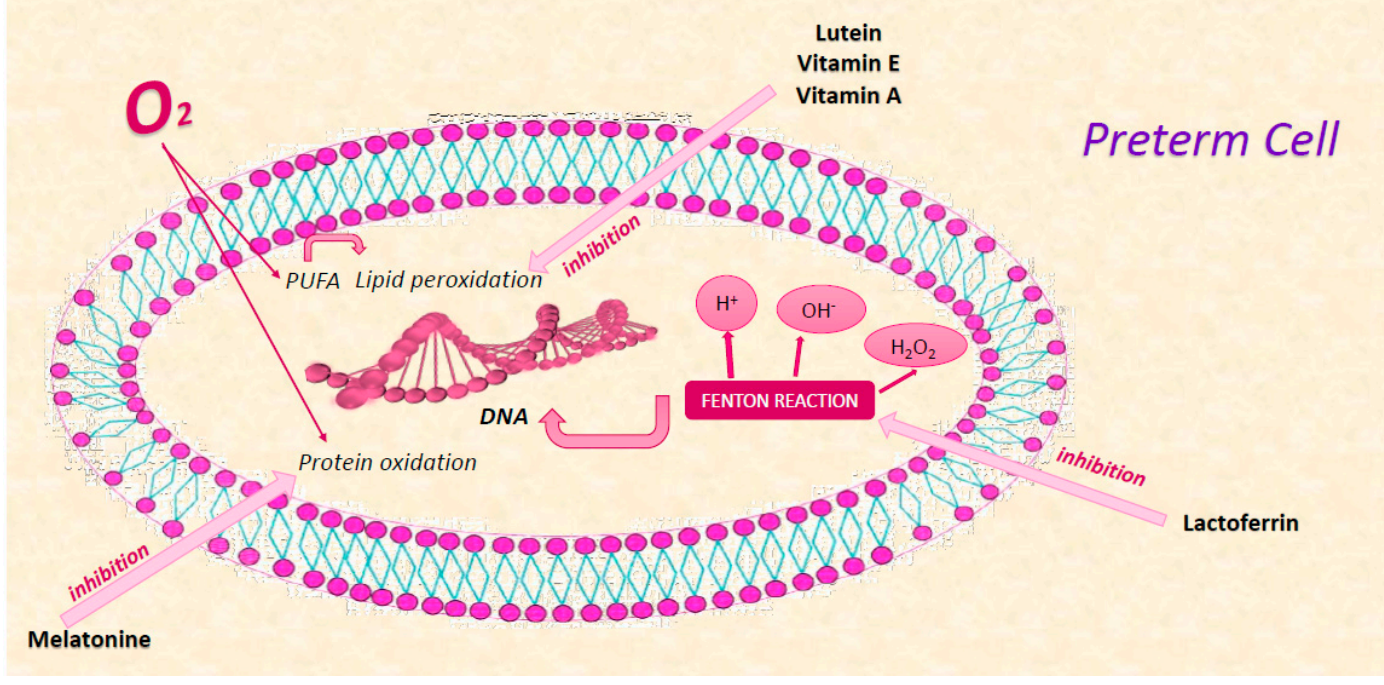

Figure 2. Drug action on cellular oxidative stress of preterm. 
Author Contributions: Conceptualization, R.F. and P.P.; methodology, F.F.; software, F.P.; validation, R.F., P.P. and F.F.; formal analysis, F.F.; investigation, F.L.; resources, M.A.N.S.; data curation, M.R.; writing-original draft preparation, F.R.; writing-review and editing, C.R.; visualization, E.P.; supervision, F.F.; project administration, R.F.; funding acquisition, P.P. All authors have read and agreed to the published version of the manuscript.

Funding: This research received no external funding.

Acknowledgments: The manuscript listed below was edited by the expert staff of American Manuscript Editors, all of whom are native English speakers. Moreover, the document was edited for proper English language, grammar, punctuation, and spelling. Certificate Verification Key: 733-393-316-163-227: Project Number: 68682.

Conflicts of Interest: The authors declare no conflict of interest. The funders had no role in the design of the study; in the collection, analyses, or interpretation of data; in the writing of the manuscript, or in the decision to publish the results.

\section{References}

1. Althabe, F.; Bhutta, Z.; Blencowe, H.; Chandra-mouli, V.; Chou, D.; Costello, A.; Cousens, S.; Davidge, R.; De Graft Johnson, J.; Dean, S.; et al. Born Too Soon: The Global Action Report on Preterm Birth; World Health Organization: Geneva, Switzerland, 2012; ISBN 9789241503433.

2. Hamilton, B.E.; Martin, J.A.; Osterman, M.J.K.; Curtin, S.C.; Matthews, T.J. Births: Final Data for 2014. Natl. Vit. Stat. Rep. 2015, 64, 1-64.

3. March of Dimes. The March of Dimes Data Book for Policy Makers: Maternal, Infant, and Health in the United States; March of Dimes: Washington, DC, USA, 2012.

4. Requejo, J.; Merialdi, M.; Althabe, F.; Keller, M.; Katz, J.; Menon, R. Born Too Soon: Care during pregnancy and childbirth to reduce preterm deliveries and improve health outcomes of the preterm baby. Reprod. Health 2013, 10 (Suppl. 1), S4. [CrossRef] [PubMed]

5. Cai, C.; Zhang, Z.; Morales, M.; Wang, Y.; Khafipour, E.; Friel, J. Feeding practice influences gut microbiome composition in very low birth weight preterm infants and the association with oxidative stress: A prospective cohort study. Free Radic. Biol. Med. 2019, 142, 146-154. [CrossRef] [PubMed]

6. Peña-Bautista, C.; Durand, T.; Vigor, C.; Oger, C.; Galano, J.-M.; Cháfer-Pericás, C. Non-invasive assessment of oxidative stress in preterm infants. Free Radic. Biol. Med. 2019, 142, 73-81. [CrossRef]

7. Stefanovic, V.; Andersson, S.; Vento, M. Oxidative stress - Related spontaneous preterm delivery challenges in causality determination, prevention and novel strategies in reduction of the sequelae. Free Radic. Biol. Med. 2019, 142, 52-60. [CrossRef] [PubMed]

8. Betteridge, D.J. What is oxidative stress? Metabolism 2000, 49, 3-8. [CrossRef]

9. Distefano, G.; Sciacca, P.; Mattia, C.; Betta, P.; Falsaperla, R.; Romeo, M.; Amato, M. Troponin I as a Biomarker of Cardiac Injury in Neonates with Idiopathic Respiratory Distress. Am. J. Perinatol. 2006, 23, 229-232. [CrossRef] [PubMed]

10. Panfoli, I.; Candiano, G.; Malova, M.; De Angelis, L.; Cardiello, V.; Buonocore, G.; Ramenghi, L.A. Oxidative Stress as a Primary Risk Factor for Brain Damage in Preterm Newborns. Front. Pediatr. 2018, 6, 369. [CrossRef]

11. Perrone, S.; Tataranno, M.L.; Negro, S.; Longini, M.; Marzocchi, B.; Proietti, F.; Iacoponi, F.; Capitani, S.; Buonocore, G. Early identification of the risk for free radical-related diseases in preterm newborns. Early Hum. Dev. 2010, 86, 241-244. [CrossRef]

12. Sies, H.; Jones, D.P. Reactive oxygen species (ROS) as pleiotropic physiological signalling agents. Nat. Rev. Mol. Cell Biol. 2020, 21, 363-383. [CrossRef]

13. Dizdaroglu, M.; Jaruga, P. Mechanisms of free radical-induced damage to DNA. Free Radic. Res. 2012, 46, 382-419. [CrossRef] [PubMed]

14. Mut-Salud, N.; Alvarez, P.; Garrido, J.M.; Carrasco, E.; Aránega, A.; Rodríguez-Serrano, F. Antioxidant Intake and Antitumor Therapy: Toward Nutritional Recommendations for Optimal Results. Oxidative Med. Cell. Longev. 2016, 2016, 1-19. [CrossRef] [PubMed]

15. Salehi, B.; Martorell, M.; Arbiser, J.L.; Sureda, A.; Martins, N.; Maurya, P.K.; Sharifi-Rad, J.; Kumar, P.; Sharifi-Rad, J. Antioxidants: Positive or Negative Actors? Biomolecules 2018, 8, 124. [CrossRef] [PubMed]

16. Moore, T.A.; Ahmad, I.; Zimmerman, M.C. Oxidative Stress and Preterm Birth: An Integrative Review. Biol. Res. Nurs. 2018, 20, 497-512. [CrossRef] 
17. Forde, D.; Deming, D.D.; Tan, J.C.; Phillips, R.M.; Fry-Bowers, E.K.; Barger, M.K.; Bahjri, K.; Angeles, D.M.; Boskovic, D.S. Oxidative Stress Biomarker Decreased in Preterm Neonates Treated with Kangaroo Mother Care. Biol. Res. Nurs. 2020, 22, 188-196. [CrossRef]

18. Lawenda, B.D.; Kelly, K.M.; Ladas, E.J.; Sagar, S.M.; Vickers, A.J.; Blumberg, J.B. Should Supplemental Antioxidant Administration Be Avoided During Chemotherapy and Radiation Therapy? J. Natl. Cancer Inst. 2008, 100, 773-783. [CrossRef]

19. Perkins, A.; Nelson, K.J.; Parsonage, D.; Poole, L.B.; Karplus, P. Peroxiredoxins: Guardians against oxidative stress and modulators of peroxide signaling. Trends Biochem. Sci. 2015, 40, 435-445. [CrossRef]

20. Valero, Y.; Martínez-Morcillo, F.J.; Esteban, M.; Chaves-Pozo, E.; Cuesta, A. Fish Peroxiredoxins and Their Role in Immunity. Biology 2015, 4, 860-880. [CrossRef]

21. Marseglia, L.; D’Angelo, G.; Granese, R.; Falsaperla, R.; Reiter, R.J.; Corsello, G.; Gitto, E. Role of oxidative stress in neonatal respiratory distress syndrome. Free Radic. Biol. Med. 2019, 142, 132-137. [CrossRef]

22. Garofoli, F. Oral Melatonin as Neuroprotectant in Preterm Infants. Available online: https://clinicaltrials.gov/ ct2/show/NCT04235673 (accessed on 22 January 2020).

23. Ain Shams University. Effect of Melatonin on Feeding Intolerance and Incidence of Necrotizing Enterocolitis in Preterm Infants. Available online: https://www.clinicaltrials.gov/ct2/show/NCT04304807 (accessed on 22 January 2020).

24. Di Fiore, J.M.; Vento, M. Intermittent hypoxemia and oxidative stress in preterm infants. Respir. Physiol. Neurobiol. 2019, 266, 121-129. [CrossRef]

25. Lavu, N.; Richardson, L.S.; Radnaa, E.; Kechichian, T.; Urrabaz-Garza, R.; Sheller-Miller, S.; Bonney, E.; Menon, R. Oxidative stress-induced downregulation of glycogen synthase kinase 3 beta in fetal membranes promotes cellular senescencet. Biol. Reprod. 2019, 101, 1018-1030. [CrossRef] [PubMed]

26. Endesfelder, S.; Strauß, E.; Scheuer, T.; Schmitz, T.; Bührer, C. Antioxidative effects of caffeine in a hyperoxia-based rat model of bronchopulmonary dysplasia. Respir. Res. 2019, 20, 88. [CrossRef] [PubMed]

27. Romantsik, O.; Agyemang, A.A.; Sveinsdóttir, S.; Rutardóttir, S.; Holmqvist, B.; Cinthio, M.; Mörgelin, M.; Gumus, H.G.; Karlsson, H.; Hansson, S.R.; et al. The heme and radical scavenger $\alpha 1$-microglobulin (A1M) confers early protection of the immature brain following preterm intraventricular hemorrhage. J. Neuroinflammation 2019, 16, 122. [CrossRef] [PubMed]

28. Büyüktiryaki, M.; Tayman, C.; Koyuncu, I.; Cakir, U.; Turkmenoglu, T.T.; Cakir, E.; Okur, N. Therapeutic and preventative effects of ankaferd blood stopper in an experimental necrotizing enterocolitis model. Biomed. Pharmacother. 2019, 110, 105-110. [CrossRef] [PubMed]

29. Millán, I.; Piñero-Ramos, J.D.; Lara, I.; Parra-Llorca, A.; Torres-Cuevas, I.; Vento, M. Oxidative Stress in the Newborn Period: Useful Biomarkers in the Clinical Setting. Antioxidants 2018, 7, 193. [CrossRef]

30. Aceti, A.; Beghetti, I.; Martini, S.; Faldella, G.; Corvaglia, L. Oxidative Stress and Necrotizing Enterocolitis: Pathogenetic Mechanisms, Opportunities for Intervention, and Role of Human Milk. Oxidative Med. Cell. Longev. 2018, 2018, 1-7. [CrossRef]

31. Martin, A.; Faës, C.; Debevec, T.; Rytz, C.; Millet, G.; Pialoux, V. Preterm birth and oxidative stress: Effects of acute physical exercise and hypoxia physiological responses. Redox Biol. 2018, 17, 315-322. [CrossRef]

32. Sun, H. Effects of Early Vitamin A Supplementation on the Risk for Retinopathy of Prematurity in Extremely Preterm Infants. Available online: https:/clinicaltrials.gov/ct2/show/NCT03154723 (accessed on 22 January 2020).

33. Torres-Cuevas, I.; Parra-Llorca, A.; Sánchez-Illana, Á.; Nuñez-Ramiro, A.; Kuligowski, J.; Cháfer-Pericás, C.; Cernada, M.; Escobar, J.; Vento, M. Oxygen and oxidative stress in the perinatal period. Redox Biol. 2017, 12, 674-681. [CrossRef]

34. Norishadkam, M.; Andishmand, S.; Reza, J.Z.; Sakhvidi, M.J.Z.; Hachesoo, V.R. Oxidative stress and DNA damage in the cord blood of preterm infants. Mutat. Res. Toxicol. Environ. Mutagen. 2017, 824, $20-24$. [CrossRef]

35. Dutta, E.H.; Behnia, F.; Boldogh, I.; Saade, G.; Taylor, B.D.; Kacerovsky, M.; Menon, R. Oxidative stress damage-associated molecular signaling pathways differentiate spontaneous preterm birth and preterm premature rupture of the membranes. Mol. Hum. Reprod. 2015, 22, 143-157. [CrossRef]

36. Yzydorczyk, C.; Mitanchez, D.; Buffat, C.; Ligi, I.; Grandvuillemin, I.; Boubred, F.; Simeoni, U. Stress oxydant chez l'enfant prématuré: Causes, biomarqueurs et possibilités thérapeutiques. Arch. Pédiatrie 2015, 22, 1047-1055. [CrossRef] [PubMed] 
37. NICHD Neonatal Research Network. Vitamin E for Extremely Preterm Infants. Available online: https: //clinicaltrials.gov/ct2/show/NCT01193270?term=Vitamin+E+for+Extremely+Preterm+Infants (accessed on 22 January 2020).

38. University of Siena. Evaluation of Antioxidant Activity of Oral Lutein in Preterm and Term Newborn. Available online: https://clinicaltrials.gov/ct2/show/NCT02068807?term=\%2C+Evaluation+of+Antioxidant+ Activity+of+Oral+Lutein+in+Preterm+and+Term+Newborn (accessed on 22 January 2020).

39. University of Siena. Upplementation with Lactoferrin in Preterm Newborns (lactoprenew). Available online: https://clinicaltrials.gov/ct2/show/record/NCT01172236 (accessed on 22 January 2020).

40. Tao, E.-F.; Yuan, T.-M. Vitamin A level and diseases of premature infants. Zhongguo Dang Dai Er Ke Za Zhi 2016, 18, 177-182.

41. Aydemir, C.; Dilli, D.; Uras, N.; Ulu, H.O.; Oguz, S.S.; Erdeve, O.; Dilmen, U. Total oxidant status and oxidative stress are increased in infants with necrotizing enterocolitis. J. Pediatr. Surg. 2011, 46, 2096-2100. [CrossRef] [PubMed]

42. Erel, O. A novel automated direct measurement method for total antioxidant capacity using a new generation, more stable ABTS radical cation. Clin. Biochem. 2004, 37, 277-285. [CrossRef]

43. Erel, O. A new automated colorimetric method for measuring total oxidant status. Clin. Biochem. 2005, 38, 1103-1111. [CrossRef] [PubMed]

44. Harma, M.; Harma, M.; Erel, O. Measurement of the total antioxidant response in preeclampsia with a novel automated method. Eur. J. Obstet. Gynecol. Reprod. Biol. 2005, 118, 47-51. [CrossRef] [PubMed]

45. Patel, R.M. Short- and Long-Term Outcomes for Extremely Preterm Infants. Am. J. Perinatol. 2016, 33, 318-328. [CrossRef]

46. Ozdemir, V. Microbiome Special Issue: Food, Drugs, Diagnostics, and Built Environments. OMICS J. Integr. Biol. 2018, 22, 89. [CrossRef]

47. Perrone, S.; Laschi, E.; Buonocore, G. Oxidative stress biomarkers in the perinatal period: Diagnostic and prognostic value. Semin. Fetal Neonatal Med. 2020, 25, 101087. [CrossRef]

48. Yang, J. The expanding landscape of the thiol redox proteome. Toxicol. Lett. 2016, 258, S43. [CrossRef]

49. McDonagh, B. Detection of ROS Induced Proteomic Signatures by Mass Spectrometry. Front. Physiol. 2017, 8, 1-7. [CrossRef]

50. Gould, N.S.; Evans, P.; Martínez-Acedo, P.; Marino, S.M.; Gladyshev, V.N.; Carroll, K.S.; Ischiropoulos, H. Site-Specific Proteomic Mapping Identifies Selectively Modified Regulatory Cysteine Residues in Functionally Distinct Protein Networks. Chem. Biol. 2015, 22, 965-975. [CrossRef] [PubMed]

51. Leichert, L.I.O.; Gehrke, F.; Gudiseva, H.V.; Blackwell, T.; Ilbert, M.; Walker, A.K.; Strahler, J.R.; Andrews, P.; Jakob, U. Quantifying changes in the thiol redox proteome upon oxidative stress in vivo. Proc. Natl. Acad. Sci. USA 2008, 105, 8197-8202. [CrossRef] [PubMed]

52. Go, Y.-M.; Roede, J.R.; Walker, D.I.; Duong, D.M.; Seyfried, N.T.; Orr, M.; Liang, Y.; Pennell, K.D.; Jones, D.P. Selective Targeting of the Cysteine Proteome by Thioredoxin and Glutathione Redox Systems. Mol. Cell. Proteom. 2013, 12, 3285-3296. [CrossRef] [PubMed]

53. Kim, H.-J.; Ha, S.; Lee, H.Y.; Lee, K.-J. ROSics: Chemistry and proteomics of cysteine modifications in redox biology. Mass Spectrom. Rev. 2015, 34, 184-208. [CrossRef] [PubMed]

54. Held, J.M. Redox Systems Biology: Harnessing the Sentinels of the Cysteine Redoxome. Antioxid. Redox Signal. 2019, 32, 659-676. [CrossRef] [PubMed]

55. Cobley, J.N.; Husi, H. Immunological Techniques to Assess Protein Thiol Redox State: Opportunities, Challenges and Solutions. Antioxidants 2020, 9, 315. [CrossRef]

56. Perrone, S.; Tataranno, M.L.; Stazzoni, G.; Buonocore, G. Biomarkers of oxidative stress in fetal and neonatal diseases. J. Matern. Neonatal Med. 2012, 25, 2575-2578. [CrossRef]

57. Frijhoff, J.; Winyard, P.; Zarkovic, N.; Davies, S.S.; Stocker, R.; Cheng, D.; Knight, A.R.; Taylor, E.L.; Oettrich, J.; Ruskovska, T.; et al. Clinical Relevance of Biomarkers of Oxidative Stress. Antioxid. Redox Signal. 2015, 23, 1144-1170. [CrossRef]

58. Tsikas, D. Analytical methods for 3-nitrotyrosine quantification in biological samples: The unique role of tandem mass spectrometry. Amino Acids 2010, 42, 45-63. [CrossRef]

59. Franco, M.C.; Estevez, A.G. Tyrosine nitration as mediator of cell death. Cell. Mol. Life Sci. 2014, 71, 3939-3950. [CrossRef] 
60. Sánchez-Illana, Á.; Parra-Llorca, A.; Escuder, D.; Pallás-Alonso, C.; Cernada, M.; Gormáz, M.; Vento, M.; Kuligowski, J. Biomarkers of oxidative stress derived damage to proteins and DNA in human breast milk. Anal. Chim. Acta 2018, 1016, 78-85. [CrossRef]

61. Torres-Cuevas, I.; Kuligowski, J.; Cárcel, M.; Cháfer-Pericás, C.; Asensi, M.; Solberg, R.; Cubells, E.; Nunez, A.; Saugstad, O.D.; Vento, M.; et al. Protein-bound tyrosine oxidation, nitration and chlorination by-products assessed by ultraperformance liquid chromatography coupled to tandem mass spectrometry. Anal. Chim. Acta 2016, 913, 104-110. [CrossRef] [PubMed]

62. Solberg, R.; Andresen, J.H.; Escrig, R.; Vento, M.; Saugstad, O.D. Resuscitation of Hypoxic Newborn Piglets With Oxygen Induces a Dose-Dependent Increase in Markers of Oxidation. Pediatr. Res. 2007, 62, 559-563. [CrossRef]

63. Ledo, A.; Arduini, A.; Asensi, A.M.; Sastre, J.; Escrig, R.; Brugada, M.; Aguar, M.; Saenz, P.; Vento, M. Human milk enhances antioxidant defenses against hydroxyl radical aggression in preterm infants. Am. J. Clin. Nutr. 2008, 89, 210-215. [CrossRef]

64. Escobar, J.; Teramo, K.; Stefanovic, V.; Andersson, S.; Asensi, M.A.; Arduini, A.; Cubells, E.; Sastre, J.; Vento, M. Amniotic Fluid Oxidative and Nitrosative Stress Biomarkers Correlate with Fetal Chronic Hypoxia in Diabetic Pregnancies. Neonatology 2013, 103, 193-198. [CrossRef] [PubMed]

65. Serhan, C.N.; Dalli, J.; Colas, R.A.; Winkler, J.W.; Chiang, N. Protectins and maresins: New pro-resolving families of mediators in acute inflammation and resolution bioactive metabolome. Biochim. Biophys. Acta (BBA)—Bioenerg. 2014, 1851, 397-413. [CrossRef]

66. Musiek, E.S.; Yin, H.; Milne, G.L.; Morrow, J.D. Recent advances in the biochemistry and clinical relevance of the isoprostane pathway. Lipids 2005, 40, 987-994. [CrossRef] [PubMed]

67. Deshpande, G.; Rakshasbhuvankar, A.; Simmer, K.; Mori, T.; Croft, K.; Currie, A. Efficacy and safety of a novel fish oil-based emulsion (SMOFlipid ${ }^{\circledR}$ ) compared with olive oil-based lipid emulsion (Cli-nOleic ${ }^{\circledR}$ ) in term and near-term (>34 weeks) surgical neonates-A randomised controlled trial. In Proceedings of the Pediatric Academic Societies (PAS) Annual Meeting, Washington, DC, USA, 4-7 May 2013. Abstract 3838.626.

68. Deshpande, G.C.; Simmer, K.; Mori, T.; Croft, K. Parenteral lipid emulsions based on olive oil compared with soybean oil in preterm $(<28$ weeks'gestation) neonates: A randomized controlled trial. J. Pediatr. Gastroenterol. Nutr. 2009, 49, 619-625. [PubMed]

69. Deshpande, G.C.; Cai, W. Use of Lipids in Neonates Requiring Parenteral Nutrition. J. Parenter. Enter. Nutr. 2020, 44 (Suppl. 1), S45-S54. [CrossRef]

70. Chavez-Valdez, R.; Ahlawat, R.; Wills-Karp, M.; Nathan, A.; Ezell, T.; Gauda, E.B. Correlation between Serum Caffeine Levels and Changes in Cytokine Profile in a Cohort of Preterm Infants. J. Pediatr. 2011, 158, 57-64. [CrossRef]

71. Manning, F.A.; Morrison, I.; Lange, I.R.; Harman, C.R.; Chamberlain, P.F. Fetal assessment based on fetal biophysical profile scoring: Experience in 12,620 referred high-risk pregnancies. Am. J. Obstet. Gynecol. 1985, 151, 343-350. [CrossRef]

72. Grosso, L.M.; Triche, E.W.; Belanger, K.; Benowitz, N.L.; Holford, T.R.; Bracken, M.B. Caffeine Metabolites in Umbilical Cord Blood, Cytochrome P-450 1A2 Activity, and Intrauterine Growth Restriction. Am. J. Epidemiol. 2006, 163, 1035-1041. [CrossRef] [PubMed]

73. Ambalavanan, N.; Carlo, W.A.; D’Angio, C.T.; McDonald, S.A.; Das, A.; Schendel, D.; Thorsen, P.; Higgings, R.D.; Eunice Kennedy Shriver National Institute of Child Health and Human Development Neonatal Research Network. Cytokines associated with bronchopulmonary dysplasia or death in extremely low birth weight infants. Pediatrics 2009, 123, 1132-1141. [CrossRef] [PubMed]

74. Goker, H.; Haznedaroglu, I.C.; Ercetin, S.; Kirazli, S.; Akman, U.; Ozturk, Y.; Firat, H.C. Haemostatic actions of the folkloric medicinal plant extract Ankaferd Blood Stopper. J. Int. Med. Res. 2008, 36, 163-170. [CrossRef] [PubMed]

75. Beyazit, Y.; Kurtm, M.; Kekilli, M.; Goker, H.; Haznedaroglu, I.C. Evaluation of hemostatic effects of Ankaferd as an alternative medicine. Altern. Med. Rev. 2010, 15, 329-336.

76. Haznedaroglu, B.Z.; Beyazit, Y.; Walker, S.L.; Haznedaroğlu, I.C. Pleiotropic cellular, hemostatic, and biological actions of Ankaferd hemostat. Crit. Rev. Oncol. 2012, 83, 21-34. [CrossRef]

77. Belizy, S.; Nasarova, I.N.; Procof'Ev, V.N.; Sorokina, I.A.; Puschkina, N.V.; Lukach, A.I. Changes in antioxidative properties of lactoferrin from women's milk during deamidation. Biochestry (Moscow) 2001, 66, 576-580. [CrossRef] 
78. Raghuveer, T.S.; McGuire, E.M.; Martin, S.M.; Wagner, B.A.; Rebouche, C.J.; Buetter, G.R.; Widness, J.A. Lactoferrin in the preterm infants' diet attenuates iron-induced oxidation products. Pediatr. Res. 2002, 52, 964-972. [CrossRef]

79. Van De Looij, Y.; Ginet, V.; Chatagner, A.; Toulotte, A.; Somm, E.; Hüppi, P.S.; Sizonenko, S.V. Lactoferrin during lactation protects the immature hypoxic-ischemic rat brain. Ann. Clin. Transl. Neurol. 2014, 1,955-967. [CrossRef]

80. Perrone, S.; Tei, M.; Longini, M.; Santacroce, A.; Turrisi, G.; Proietti, F.; Felici, C.; Picardi, A.; Bazzini, F.; Vasarri, P.; et al. Lipid and Protein Oxidation in Newborn Infants after Lutein Administration. Oxidative Med. Cell. Longev. 2014, 2014, 1-7. [CrossRef]

81. Ramani, M.; Van Groen, T.; Kadish, I.; Ambalavanan, N.; McMahon, L.L. Vitamin A and retinoic acid combination attenuates neonatal hyperoxia-induced neurobehavioral impairment in adult mice. Neurobiol. Learn. Mem. 2017, 141, 209-216. [CrossRef] [PubMed]

82. Yawno, T.; Mahen, M.; Li, J.; Fahey, M.C.; Jenkin, G.; Miller, S.L. The Beneficial Effects of Melatonin Administration Following Hypoxia-Ischemia in Preterm Fetal Sheep. Front. Cell. Neurosci. 2017, 11, 296. [CrossRef] [PubMed]

83. Acuna-Castroviejo, D.; Martin, M.; Macias, M.; Escames, G.; Leon, J.; Reiter, R.J. Melatonin, mitochondria, and cellular bioenergetics. J. Pineal Res. 2001, 30, 65-74. [CrossRef] [PubMed]

84. Pandi-Perumal, S.R.; Bahammam, A.S.; Brown, G.M.; Spence, D.W.; Bharti, V.K.; Kaur, C.; Hardeland, R.; Cardinali, D.; Pandi-Perumal, S.R. Melatonin Antioxidative Defense: Therapeutical Implications for Aging and Neurodegenerative Processes. Neurotox. Res. 2012, 23, 267-300. [CrossRef]

85. Fu, J.; Zhao, S.-D.; Liu, H.-J.; Yuan, Q.-H.; Liu, S.-M.; Zhang, Y.; Ling, E.-A.; Hao, A. Melatonin promotes proliferation and differentiation of neural stem cells subjected to hypoxia in vitro. J. Pineal Res. 2011, 51, 104-112. [CrossRef] [PubMed]

86. Villapol, S.; Fau, S.; Renolleau, S.; Biran, V.; Charriaut-Marlangue, C.; Baud, O. Melatonin Promotes Myelination by Decreasing White Matter Inflammation After Neonatal Stroke. Pediatr. Res. 2011, 69, 51-55. [CrossRef] [PubMed]

87. Hardeland, R.; Tan, D.-X.; Reiter, R.J. Kynuramines, metabolites of melatonin and other indoles: The resurrection of an almost forgotten class of biogenic amines. J. Pineal Res. 2009, 47, 109-126. [CrossRef]

88. Tan, D.-X.; Manchester, L.C.; Terron, M.P.; Flores, L.J.; Reiter, R. One molecule, many derivatives: A never-ending interaction of melatonin with reactive oxygen and nitrogen species? J. Pineal Res. 2007, 42, 28-42. [CrossRef] [PubMed]

89. Hassell, K.J.; Ezzati, M.; Alonso-Alconada, D.; Hausenloy, D.J.; Robertson, N.J. New horizons for newborn brain protection: Enhancing endogenous neuroprotection. Arch. Dis. Child. Fetal Neonatal Ed. 2015, 100, F541-F552. [CrossRef]

90. Gollwitzer, E.S.; Saglani, S.; Trompette, A.; Yadava, K.; Sherburn, R.; McCoy, K.D.; Nicod, L.P.; Lloyd, C.M.; Marsland, B.J. Lung microbiota promotes tolerance to allergens in neonates via PD-L1. Nat. Med. 2014, 20, 642-647. [CrossRef]

91. Nardiello, C.; Mižíková, I.; Silva, D.M.; Ruiz-Camp, J.; Mayer, K.; Vadász, I.; Herold, S.; Seeger, W.; Morty, R.E. Standardisation of oxygen exposure in the development of mouse models for bronchopulmonary dysplasia. Dis. Model. Mech. 2016, 10, 185-196. [CrossRef] [PubMed]

92. Berkelhamer, S.K.; Kim, G.A.; Radder, J.E.; Wedgwood, S.; Czech, L.; Steinhorn, R.H.; Schumacker, P.T. Developmental differences in hyperoxia-induced oxidative stress and cellular responses in the murine lung. Free Radic. Biol. Med. 2013, 61, 51-60. [CrossRef] [PubMed]

93. Segal, L.; Clemente, J.C.; Wu, B.; Wikoff, W.R.; Gao, Z.; Li, Y.; Ko, J.P.; Rom, W.N.; Blaser, M.J.; Weiden, M.D. Randomised, double-blind, placebo-controlled trial with azithromycin selects for anti-inflammatory microbial metabolites in the emphysematous lung. Thorax 2016, 72, 13-22. [CrossRef] [PubMed]

94. Pellaton, C.; Nutten, S.; Thierry, A.-C.; Boudousquie, C.; Barbier, N.; Blanchard, C.; Corthésy, B.; Mercenier, A.; Spertini, F. Intragastric and Intranasal Administration of Lactobacillus paracasei NCC2461 Modulates Allergic Airway Inflammation in Mice. Int. J. Inflamm. 2012, 2012, 1-8. [CrossRef] [PubMed]

95. Yun, Y.; Srinivas, G.; Kuenzel, S.; Linnenbrink, M.; Alnahas, S.; Bruce, K.D.; Steinhoff, U.; Baines, J.F.; Schaible, U.E. Environmentally Determined Differences in the Murine Lung Microbiota and Their Relation to Alveolar Architecture. PLoS ONE 2014, 9, e113466. [CrossRef] [PubMed] 
96. Collins, J.; Tibboel, D.; De Kleer, I.M.; Reiss, I.K.M.; Rottier, R.J. The Future of Bronchopulmonary Dysplasia: Emerging Pathophysiological Concepts and Potential New Avenues of Treatment. Front. Med. 2017, 4, 61. [CrossRef]

97. Capasso, L.; Vento, G.; Loddo, C.; Tirone, C.; Iavarone, F.; Raimondi, F.; Dani, C.; Fanos, V. Oxidative Stress and Bronchopulmonary Dysplasia: Evidences from Microbiomics, Metabolomics, and Proteomics. Front. Pediatr. 2019, 7, 30. [CrossRef] 